\title{
CUIDADOS, MOBILIDADE E PODER NUM CONTEXTO DE EPIDEMIA: RELAÇÕES FAMILIARES E ESPAÇOS DE NEGOCIAÇÃO
}

Parry Scott ${ }^{1}$

${ }^{1}$ Universidade Federal de Pernambuco, Recife, PE, Brasil

Quando o Brasil se descobriu foco da epidemia da Síndrome Congênita do Zika (SCZ), classificada como Emergência Pública de Interesse Internacional pela Organização Mundial de Saúde, de fevereiro a novembro de 2016, foram consolidados domínios de biopoder, em serviços de atendimento e em formulação de conhecimento, que exigiam respostas de mães que enfrentavam o desafio de cuidar de filhos afetados pelo vírus. Este trabalho, realizado no estado de Pernambuco, tem como foco relações familiares nas práticas dessas mães decorrentes da epidemia. A ênfase recai em locais de moradia, redes sociais próximas e transporte em razão de o envolvimento nestas atividades recorrentemente constituir pontos críticos na elaboração de itinerários terapêuticos fundamentais para buscar os cuidados mais adequados para os seus filhos.

De bairros populares, em sua maioria, as mães de filhos com SCZ se engajam em rotinas de dedicação exaustiva à maternidade, questão criticada por ondas históricas do feminismo (Firestone 1970), mas fundamentais para a criação de cidadania, própria e do filho, no caso em tela. Ao contrário de sofrerem acusações morais que realçam sexualidade e individualidade exacerbadas, dirigidas a mães que negam a maternidade que Fernandes $(2018,2017)$ ilustra como casos de mulheres "novinhas, nervosas e abandonantes", as mães de filhos SCZ recebem elogios por sua dedicação, abnegação e seu sacrifício. O reforço moral proveniente da devoção à maternidade é acompanhado por profundas mudanças nas suas práticas de residência, de relações familiares e de deslocamentos diários. Mas diante da circunscrição de grande parte das suas práticas cotidianas a cuidados dos 
seus dependentes, os seus contatos com outros domínios da área de serviços por elas requeridos (saúde, transporte, assistência social, pensões, educação) fazem com que os seus "territórios de existência" também se alarguem. E isto é acentuado através de alianças com outras mães em associações. Assim como as mães que estabelecem relações de tensão ou negação da maternidade, presentes na etnografia de Fernandes, elas enfrentam ausências masculinas e lacunas e carências do Estado, mas da sua super-restrição aos cuidados, além do sofrimento, retiram uma maior capacidade de enquadrar e defender as suas demandas coletivamente.

Cada atividade confrontada é composta de distintas configurações de domínios de poder que resultam numa variabilidade de espaços de negociação onde as mães precisam realizar práticas que possam favorecê-las e também o cuidado dos seus filhos no contexto da epidemia e da pósepidemia em que estão inseridas como sujeitas priorizadas através do vínculo com o filho. Os seus sofrimentos e como aliviá-los são a razão de ser da formação de intensas e complexas teias relacionais e institucionais de profissionais especializados no campo da saúde e sujeitas à economia política desde o nível local até o global em torno da solução dos problemas que as atingem.

Não tem porque de uma negociação ser entre iguais. Acompanhando a lógica de Bourdieu sobre campos e seus habitus (1992), os espaços onde as negociações ocorrem estão eivados de hierarquizações relacionadas com valorizações sociais gerais que se colocam em jogo quando diferentes agentes interagem nesses espaços. Em resumo, qualquer foco em negociação é relacionalmente tensionado por contrapor perspectivas de agentes em domínios de poder situados. O domínio de poder, associado sempre a práticas específicas de relações entre pessoas, foi descrito por Adams (1975), inspirado em Max Weber e Leslie White, como a capacidade de um ator fazer com que outro faça o que o primeiro quer através do controle de processos energéticos no ambiente que o interessa. Na sua teoria de poder social, um domínio de poder é um espaço caracterizado por controles diferenciados de partes de um ambiente (simbólico e material) feitos por atores e que resultam no estabelecimento de uma relação de poder entre eles. Cada um dos atores aciona esses controles e, em consequência, influencia as ações de outras pessoas.

Neste trabalho, ao focar em mães e seus filhos com a SCZ num contexto de epidemia, entende-se que elas controlam o acesso aos filhos como corpos afetados pelo vírus num ambiente em que, ao mesmo tempo em que são priorizadas, também são subordinadas e sujeitas a tensão. Elas controlam a parte do ambiente que interessa aos especialistas em saúde que se dedicam 
a lidar com as maneiras pelas quais o vírus prejudica as condições de vida dessas crianças, com a demanda aos sistemas de saúde em condições de atenderem aos doentes, e desafiam o próprio conhecimento sobre as características e o comportamento da doença. Argumento que as mães recorrem a referências a relações e a simbologias de famílias ${ }^{1}$, numa prática que marca os seus esforços de conseguir os cuidados que elas julgam ser os mais adequados para os filhos nos domínios nos quais circulam, conseguindo extrapolar os limites dos domínios associados à epidemia.

Na era da globalização, o campo do direito e dos direitos se tornou um mecanismo de articulação da diversidade que permite referência a múltiplas reivindicações em redes transversais que recortam espaços outrora percebidos como relativamente mais indivisos. Ideias sobre família(s) se tornam uma moeda para alcançar outros fins, sem negar, ou mais ainda, aproveitando, a positividade que o termo costuma conotar. Em outras palavras, a judicialização de significados sociais e o reconhecimento de múltiplas agências tanto abrem quanto fecham espaços para negociação, e a família é uma referência simbólica maleável, comumente invocada como elemento positivo nessas negociações.

Na epidemia de Zika, as mães procuram as instituições que oferecem atendimentos que viabilizem os cuidados de seus filhos, o que implica enfrentar serviços disponibilizados de maneiras diversas e buscar informações sobre saúde, frequentemente difíceis de obter. Historicamente essas instituições são associadas a ideias sobre a burocracia e ao discurso da crise de saúde pública. Em sua pesquisa sobre administração e litígios de saúde em tempos de crise, o antropólogo Lucas Freire (2019) argumenta que nas práticas burocratizadas contínuas é "a naturalização da escassez que sustenta e permite a expansão contínua de projetos de 'restruturação de serviços' e 'repactuação de direitos' (:265) como modo de governo". Também ressalta que "o enquadramento das experiências vivenciadas como conformadoras de uma 'conjuntura de crise' demanda que algo seja feito em um curto prazo, gerando uma crise que pode ser entendida enquanto uma situação que precisa ser governada" (:49). A ocorrência de uma epidemia é uma conjuntura que exige ação a curto prazo. Uma epidemia movimenta uma quantidade incomum de recursos (apenas aparentando um contraponto à escassez cotidiana, porque há lugares onde tais recursos não chegam), e nesta situação oferece oportunidades de intensificação de reestruturações supostamente mais sensíveis aos direitos das vítimas da epidemia, reestruturações estas que podem se desarticular ou não quando a epidemia for declarada sob controle pelos gestores, que se identificam com quem dá resposta a ela. 
Três agentes se interconectam por ocasião de pandemia: doentes (e suas famílias), profissionais de serviços e pesquisadores. No caso da Zika, todos vão cuidar da criança afetada e da família, do jeito que lhes cabe. Trabalham em domínios que têm uma intensa relação entre si, mas que se delineiam por princípios diferentes. Resumidamente, em termos ideais (que abordaremos mais adiante neste trabalho), o domínio de cuidado dos doentes e familiares destaca a qualidade das relações e dos vínculos de pertencimento e proximidade na vida cotidiana; o domínio de atendimento na prestação de serviços de saúde (e outros serviços relevantes) cuida da efetividade do atendimento aos que adoecem; e o domínio de conhecimento da doença e suas características é realçado por pesquisadores ansiosos em descobrir rapidamente como debelar a doença (Scott 2020).

\section{A epidemia e a convocação de pesquisas}

A epidemia do Zika vírus, transmitida por uma picada de mosquito (Aedes Aegypti), bem como sexualmente, afetou 3.194 bebês no Brasil, sendo 455 em Pernambuco (Barbosa et al 2020:1). ${ }^{2}$ A epidemia foi primeiro reconhecida pelo alto número de recém-nascidos com microcefalia no final de 2015, e rapidamente problematizada política e economicamente por Diniz (2016). Foram instauradas investigações por pesquisadoras, entre as quais foram incluídas as mesmas profissionais que atendiam às parturientes e seus bebês. As pesquisas prosseguiram com grupos especiais de profissionais que se uniram e organizaram diversas pesquisas e vários atendimentos em mutirões para terem acesso aos corpos dos bebês e das crianças, sobressaindo-se metodologias epidemiológicas. Descobriram problemas neurológicos, inclusive em bebês que não apresentavam microcefalia, convulsões repetidas, disfagia, problemas oftalmológicos, ortopédicos, respiratórios, ambulação limitada e, em geral, desenvolvimento muito prejudicado (Albuquerque et al. 2018). A alta mortalidade, em torno de $10 \%$ em três anos (Barbosa et al. 2020), sempre presente como preocupação, não impede que grande número de mães continue com rotinas diárias intensas de levar seus filhos a terapias, consultas, exames e ainda internamentos dos mais diversos tipos. A vida cotidiana das mães cuidadoras de crianças SCZ gira em torno de pesquisadores, profissionais e trabalhadores de serviços de saúde, e ainda se estende para outros serviços (especialmente transporte, previdência, assistência social e educação).

A chamada 014 de 2016 sobre Prevenção e Combate ao vírus Zika (CNPq, CAPES, DECIT-MS) foi uma das ações de reorganização de instituições através de equipes de pesquisadores multi-institucionais 
(quase sempre com integrantes locais, nacionais e internacionais). O projeto “Etnografando Cuidados e Pensando Políticas de Saúde e Gestão de Serviços para Mulheres e Seus Filhos com Distúrbios Neurológicos Relacionados com Zika em Pernambuco, Brasil", ${ }^{3}$ que embasa este trabalho, foi aprovado como o único de abordagem antropológica entre os 71 aprovados que participaram em quatro anos de pesquisa, com reuniões anuais em Brasília, para compartilhar informações. O alto número de projetos e a vultosa quantia de recursos (R\$ 65 milhões) sinalizaram a vontade nacional de lidar com velocidade e com competência seletiva em face da epidemia brasileira, que se tornou internacional. Os participantes dos projetos mostraram desde o início nas suas reuniões de compartilhamento (designadas de "avaliações" pelos organizadores) que seriam provocadas subdivisões entre pesquisadores que conversariam muito entre si, mas pouco com os outros. Para conseguir reunir em poucos dias pesquisadores e para respeitar as afinidades entre eles, foram divididos em quatro subgrupos (GT1 - diagnóstico, imunobiologia, imunologia e virologia; GT2 - tecnologias sociais e inovação, inovação em gestão e serviços, epidemiologia e vigilância; GT3 - avaliação de repelentes, controle de vetores; GT4 - fisiopatologia e clínica). Quase não houve oportunidades de diálogos entre grupos, cujos pesquisadores apenas se encontravam na hora da assembleia inicial e das refeições, já sinalizando com clareza que o campo de conhecimento sobre Zika se dividia de antemão em domínios distintos. Isto se repetiu, porém com diferentes categorias, na pesquisa de campo sobre "etnografando cuidados".

A nossa pesquisa, ao longo dos quatro anos, ${ }^{4}$ contou com uma equipe de cinco pesquisadores principais (docentes e pesquisadores com doutorado em antropologia), 13 discentes e três bolsistas de apoio técnico. Parte da equipe acompanhou os itinerários terapêuticos das mães e das crianças, e parte se concentrou nos gestores, profissionais e prestadores de serviços, com uma expressa intenção de usar esta informação conseguida em anotações de observações em campo (como descreve Fleischer 2018; Fleischer \& Lima $2020^{5}$ ), com 112 entrevistas transcritas, pesquisa documental e participação em eventos e coparticipação de instituições nacionais e estrangeiras.

Inicialmente pensamos em selecionar mães com crianças em diferentes comunidades de acordo com incidência de Zika e protocolos, conseguindo permissão do Comitês de Ética gerais e específicos ${ }^{6}{ }^{6}$ mas desde as primeiras tentativas em campo ficou evidente que outro caminho seria mais adequado por causa da alta empatia e dinamicidade das Associações de Mães que estavam em contato constante cotidiano e solidário com as mães do que o caminho técnico. Primeiro, participamos da AMAR (Aliança de Mães e Famílias Raras), cuja associação foi formada antes da epidemia. 
Em seguida, participamos mais intensivamente da União de Mães de Anjos (UMA), exclusiva para mães de crianças com microcefalia e outras sequelas causadas pela Síndrome Congênita do Zika. Ambas as associações são presididas por mães de filhos especiais, e dedicadas a unir mães para lutar por seus filhos e por si mesmas, suas cuidadoras. Uma vez encontradas as mães nesses ambientes, prevaleceu um processo de acompanhamento individual de mães e filhos nos seus itinerários, expressamente terapêuticos ou não, formando uma relação muito alinhada com elas (Scott \& Lira 2020; Lira et al. 2017). Os gestores, profissionais e outros pesquisadores foram procurados nesses e em outros espaços condizentes com as suas responsabilidades.

Nos cenários provocados pela epidemia, as pressões para as mães reorganizarem a sua mobilidade e a participação de pessoas nas suas redes de relações associadas a cuidados estavam sempre presentes para todas, levando à escolha de temas para este trabalho. Ao preferir focar em três narrativas de mães que passaram por esta experiência com a epidemia da SCZ em Pernambuco, possibilita-se uma compreensão aprofundada das consequências das suas estratégias de mobilidade para a formação de redes de apoio, a realização efetiva de cuidados e a negociação de poder e busca por direitos. A personalização das narrativas favorece uma leitura mais densa, e a grande dimensão de toda a pesquisa permite que se possa mostrar quando uma experiência pessoal se afasta do conteúdo geral do conjunto completo de mães e crianças, bem como de gestores e profissionais. Também reflete como cada um de nós, pesquisadores, vivemos esta experiência de pesquisa "alinhada". São histórias eivadas de ambiguidades. São mobilidades extraordinariamente limitadoras da vida. A sensação de não se estar fazendo outra coisa na vida que não seja cuidar do filho produz um efeito centrípeto. Ao mesmo tempo mover-se permite providenciar os serviços necessários ao filho, produz a consciência de que se está conseguindo fazer alguma coisa muito especial.

Cada demanda para mobilidade apresenta alguns domínios de poder dentro dos quais as famílias precisam negociar. Nesses domínios aparecem brechas e obstáculos, e o acionamento da demanda "familiar", de ser de um grupo doméstico que precisa cuidar de alguém, é uma chave que opera com regularidade nessas negociações. O ponto de partida principal da criação de uma ênfase discursiva na família é a disposição de emprestar o próprio corpo da mãe ao bebê, sendo os olhos de quem enxerga mal, as pernas de quem não consegue andar, a voz de quem não sabe falar etc. É mais uma reificação da díade materno-infantil que insiste na conexão entre os dois corpos. Cria um corpo mais forte demandante para poder doar os esforços ao corpo mais frágil, a ele conectado. Estas questões remetem à criação de 
bioidentidades (Rabinow 2002; Rose 2013) e à formação de um corpo múltiplo que se apresenta diferentemente de acordo com a perspectiva de quem observa o que nele (Mol 2002, 2008), ou de como pensa em protagonizar as suas demandas.

Nesta perspectiva, a mobilidade de acesso ao transporte cotidiano para ir e vir de locais de atendimento é apenas parte de uma miríade de deslocamentos sociais, espaciais e simbólicos que reorganizam a vida das mães e das famílias. O movimento constante das mães simultaneamente fortalece o seu isolamento e o seu sentimento de pertencimento a uma coletividade para negociar os seus direitos. Por esta razão, é abordada aqui através de mudanças de locais de residência, de escolhas de participação em redes relacionais, além da realização de mobilidade cotidiana em busca de atendimento. Transformando num linguajar de direitos, inclui 1 . o direito a centros de tratamento próximos à sua residência; 2. o direito a deslocamentos regulares de qualidade para ter acesso aos locais de tratamento; e 3. a convivência e a proximidade com pessoas dispostas a ajudar no cuidado, incluindo e excluindo pessoas da rede familiar, da vizinhança e da vida associativa.

Uma das maiores dificuldades das famílias é lidar com a necessidade de se mobilizar e de conseguir coparticipação em cuidados. Por isso, destacamos as negociações que têm lugar nos locais de residência, na participação em redes relacionais e na mobilidade cotidiana ao longo do trabalho. As considerações finais discutem os conteúdos dos casos examinados, enfatizando a onipresença das famílias, através das práticas das mães, e selecionando características a elas associadas, como a coletivização em associações de mães, que tiveram como efeito torná-las mais fortes diante do contexto emergencial particular que poderia subalternizá-las ainda mais.

\section{Mobilidades, cuidados e domínios de poder na epidemia do Zika}

Neste contexto de domínios de cuidado entrecruzados, a necessidade de mobilidade afeta todos. Pesquisadores e profissionais reorganizam equipes e prestam serviços numa diversidade de grupos e instituições que exigem presença e trocas de informações constantes por sua relevância para atender a doentes e conhecer a doença. E para os doentes e seus familiares as exigências são maiores ainda, pois os que adoecem moram num determinado lugar e com pessoas a que chamam de família e, via de regra, vão continuar morando com as mesmas pessoas ou com recombinações de pessoas que 
vão chamar de família, e num lugar tão adequado quanto possível para as necessidades de tratar a pessoa que adoece. Como o adoecimento resulta em sequelas mais duradouras que exigem cuidados redobrados em vez de recuperação rápida, é ainda mais provável que a mobilidade familiar seja cogitada com mudanças de locais de residência e inclusão e exclusão de pessoas na casa de acordo com a sua disposição de colaborar.

A mobilidade cotidiana, as recomposições do grupo doméstico e as mudanças residenciais raras vezes são monocausais. Antes do nascimento de um filho com microcefalia, integrantes de todos os grupos domésticos conviveram com os desafios de chegar no seu trabalho e em serviços de saúde, educação etc.; com a decisão sobre romper ou continuar a corresidência com parceiros, outras gerações e outros parentes; ou em pensar em migrar para tentar a vida sob novos horizontes. O nascimento de um filho que exige cuidados intensivos é uma superposição deste fator sobre as outras demandas de deslocamentos na vida. Permite a formação de redes mais estreitas ou mais frouxas em domínios diversos que possibilitam cuidar (ou não cuidar) do/a filho/a. Como ressalta Fernandes (2018), a administração do tempo mistura o "tempo de ficar com a criança" e o "tempo de correr atrás", ou ainda de estar mais próxima das realidades destas mães de deficientes, o que Nelvo (2020: IV, 7) chama de "o trabalho do tempo", sendo uma "trama complexa envolvendo as dificuldades triviais em torno da reivindicação política da 'vida possível de ser vivida'", constituída por um tempo (passado, presente e futuro) que não é linear, mas sim circular, cotidianamente reeditado e reinterpretado.

Segundo Scott (2020), entre uma diversidade de domínios e de subdivisões internas de domínios, uma epidemia favorece a presença forte e atuante de três domínios - relacional, de atendimento e de conhecimento - que buscam controlar partes diferentes do ambiente, mas que convergem no sentido de o corpo adoecido ser uma fonte básica para todos. Seguindo a repetida advertência de estudos sobre cuidados (Hirata 2016; Tronto 1997; Ayres 2004), a contextualização de espaços onde ocorrem cuidados exige que compreendamos os atores diferentes envolvidos em relação a ele. ${ }^{7}$

As mães estão elaborando as suas próprias estratégias de formação de grupos domésticos e de convivência próximas de outras pessoas, parentes e não parentes, na qual a relação de solidariedade entre as pessoas, mesmo se às vezes tensa, é um elemento duradouro. Estudiosos sobre parentesco que têm desdobrado as sugestões de Schneider (1968) mostram que este domínio usa, mas ultrapassa em muito, imagens de sangue e relações reforçadas pelo pertencimento mútuo de substâncias biológicas, para incluir ideias de solidariedade e de longa duração ("para a vida toda"), ou mesmo, às vezes, 
de curta duração, a depender da qualidade do vínculo entre as pessoas (Giddens 1993; Carsten 2004; Fonseca 2007). Sempre se considera a possibilidade de escolha ou não de continuidade da relação. Com a presença de uma criança afetada pela SCZ, estes fatores sofrem abalos e fortalecimentos que exigem recomposições. A este domínio das mães e das suas crianças, afetadas pela SCZ, designamos de domínio relacional.

O segundo domínio presente no cotidiano de serviços e nas epidemias é o domínio de atendimento , que é relativo a gestores e profissionais de serviços de saúde e de outros serviços relacionados, ${ }^{8}$ e envolve sistemas atrelados a ofertas e organizados por burocracias e instituições que gestam serviços de saúde (e também de educação, transporte, previdência e outras formas de assistência social), de acordo com as políticas que regem os setores onde operam. Conseguir lidar com as demandas dos corpos adoecidos, mais fortemente sentidas pelos serviços de saúde, porém compartilhadas com os outros, e em conformidade com a regulamentação e as políticas vigentes nos seus setores, de acordo com os conhecimentos existentes e as forças e as fragilidades da disposição de recursos para as suas atividades, constituem questões mais prementes que a questão relacional realçada por mães e crianças (ver Silva et al. 2017).

O terceiro, o domínio do conhecimento, em interação com o domínio de atendimento e com o domínio relacional dos adoecidos, atrai um grande número de pesquisadores que visam identificar as características da doença, desde a sua etiologia, história natural, patologia até a descoberta de remédios eficazes no seu tratamento. O corpo adoecido é mais uma fonte de informação de que um sujeito a ter os seus males aliviados neste domínio. Especialmente quando os remédios são desconhecidos (seja em função da novidade da doença, seja em função da dificuldade de comprovar eficácia), a realização de estudos e observações exige a criação de procedimentos de estudo altamente padronizados. Petryna (2011) e Silva (2018) argutamente destrincham algumas lógicas da economia política da experimentação farmacêutica que obedece a uma regulamentação rígida de procedimentos em ensaios clínicos, cujos custos podem ser amenizados no encontro de corpos adoecidos em locais distantes onde há sujeitos para experimentação facilitada com maior fragilidade das práticas e das legislações, entendidas como variabilidade ética por Petryna.

Na sua tese, Rosana Silva (2018) intitula sinteticamente esta situação de maior fragilidade de "precariedades oportunas". Sem a pesquisa, não se conhece de forma tão profunda a doença para se poder ter certeza do tratamento, e sem o doente que está sujeito a experimentação, não se chega a este conhecimento. $\mathrm{O}$ custo de tal empreendimento de gerar conhecimento 
contribui tanto para a dilapidação da saúde de alguns quanto para a melhora de outros, e esta diferenciação aponta desigualdades notáveis. No curto prazo de uma epidemia, este domínio ganha força pelo potencial de movimentar intensivamente o acesso a recursos de pesquisa e de produção de serviços e remédios (ver Freire 2019).

Os percursos terapêuticos seguidos pelas mães tomam a forma do que Bonet (2014) prefere chamar de "itinerações" para realçar movimento, criação e a variabilidade construída por cada sujeito na sua movimentação entre relações e não "entidades". Nas suas palavras:

Nesses deslocamentos pelo sistema de saúde, os usuários vão estruturando o próprio sistema, o que frequentemente não coincide com a estrutura que os gestores pensaram para ele. Em outras palavras, ao se movimentarem pelos serviços, os usuários tomam decisões e, com elas, vão construindo uma história. (:335)

Cada domínio descrito aqui é uma multiplicidade de malhas de relações formadas pelas pessoas cujas linhas de vida se entrelaçam e criam uma flexibilidade que extrapola em muito as delimitações aqui sugeridas, gerando muitas histórias. Isto fica evidente quando acompanhamos as experiências de mães cuja vida "possível de viver" (Nelvo 2020) extrapola os ditames de relações que caracterizam os domínios.

\section{Três mães, filhos e famílias}

Quem são as três mães, os três filhos e as três famílias cujas experiências são relatadas aqui? Uma família é da Região Metropolitana do Recife. Outra é de 100 a 150 quilômetros do Recife, na zona do Agreste de Pernambuco. E a terceira é de 300 a 350 quilômetros do Recife, na zona do Sertão. Nesta etnografia utilizaremos os seguintes nomes fictícios: Renata do Recife, cujo filho é Roberto; Ágata do Agreste, cujo filho é Artur; e Selma do Sertão, cuja filha é Sandra. Os filhos com SCZ nasceram nos últimos meses de 2015. São mães com 27 anos e dois filhos; com 30 anos e quatro filhos, e com 31 anos e quatro filhos, respectivamente. Todas residiam próximas de suas mães (as avós dos bebês) na hora do nascimento do filho com SCZ. Renata continua morando com o primeiro marido. Ágata, separada, e Selma, viúva, estão em união com o segundo marido. Todas procedem de bairros populares e vivem uma relativa estabilidade, combinando atividades próprias de ganhar renda com trabalho um pouco mais precário dos seus maridos. 


\section{Mobilidade e redes sociais}

Como muitas outras, as três mulheres têm trajetórias de redefinição das redes sociais de apoio da vida cotidiana com os seus casamentos, dedicação ao trabalho e aos cuidados de filhos. Como "quem casa, quer casa", não morar mais na casa da mãe permitiu um relacionamento mais estreito e colaborativo com o marido e acrescentou uma aproximação com uma rede de parentes afins, incluindo sogros e cunhados. Abriu espaço para amizades mútuas para todas as mães. Mesmo assim, não havia grandes distâncias entre as suas residências novas e as dos pais e sogros, ou melhor, das mães e sogras pela predominância de mulheres nestas atividades. Visitas e compartilhamentos de cuidados eram comuns.

Selma, ainda adolescente, engravidou e casou com um rapaz trabalhador da sua idade que conhecia há tempo. Como castigo pela gravidez, o pai a expulsou de casa. Foi morar mais próximo da família do rapaz. Sem deixarem de estudar, conseguiram se sustentar e criar uma reputação com bons trabalhos no município, ele, empregado, e ela, vendedora, o que exigia comunicação com os outros. Com dois filhos, a relação estava em dissolução quando um acidente de moto a enviuvou. Pouco tempo depois, ela se uniu a um segundo marido mais velho, de condições e de iniciativas menores. Começou uma vida de deslocamentos quando assumiu a gerência de um restaurante num município próximo, sem deixar as suas vendas. Cada vez mais dependia de si mesma, ainda levando os dois filhos para morar com ela na cidade nova. O marido ficou na cidade de origem, para onde ia com muita frequência, mantendo laços familiares e compartilhando renda.

Ágata também casou jovem e teve dois filhos com o primeiro marido. Sempre residiu relativamente próxima dos seus pais e dos pais do marido. Depois de alguns anos e dois filhos, a relação se desfez. Ela se casou com outro homem, pai dos seus últimos dois filhos, um deles Artur. Para que Ágata pudesse continuar trabalhando no supermercado depois da separação, sua mãe assumiu os primeiros dois filhos para criar em sua casa. O novo marido, motorista bem empregado, trouxe mais estabilidade financeira. Ainda contava com a contribuição da sogra, que continua pagando um plano de saúde. Então, com sua mãe colaborando com a criação dos dois primeiros filhos, o casal e seus filhos viviam uma vida corrida, com condições financeiras medianas, embora não sem apertos. Quando nasceu Artur, pensaram seriamente em complementar o tratamento público com terapias de qualidade na rede particular para o filho. 
Renata do Recife, a mais nova das mães, tinha vindo jovem para o Recife com a família. Quando se casou, ficou ainda morando próxima da mãe, no andar superior de uma casa pequena, num bairro popular, em rua plana e movimentada no oeste do Recife. O primeiro filho nasceu em 2014. Cuidando dele, ela decidiu que não poderia continuar ativa no trabalho no setor de estética. O marido também achou importante que ela dedicasse tempo cuidando do bebê novo. A ideia de não poder trabalhar ficou ainda mais forte com a chegada da gravidez de Roberto.

Resumindo, as três mulheres tinham trajetórias de dedicação ao trabalho e de saídas de casa que implicaram rearranjos domiciliares para estabelecer os seus laços conjugais. Embora Selma tenha sido expulsa de casa, sempre contou com a colaboração materna. Ágata e Renata também, mesmo morando em casas separadas, viviam a proximidade cotidiana das mães na vizinhança. A convivência com maridos, se antes foi a chave para estabelecer um grupo doméstico à parte, também exigiu redefinições de relações com a própria família de origem e a dos maridos.

Ao prosseguir com a reorganização dos seus grupos domésticos, decorrentes da presença de novos maridos (Ágata por ser separada e Selma por ter enviuvado), o segundo casamento foi um passo para reconhecer a necessidade de mudar a mobilidade e modificar a participação em redes sociais de parentesco, consanguíneos e afins, sempre atrelado também às condições financeiras. Para Renata e o marido, a decisão de deixar de trabalhar desde o primeiro filho trouxe resultados semelhantes na rotina entre eles, mas sem mobilidade residencial. $O$ advento do bebê com a Síndrome Congênita de Zika operou a intensificação da necessidade de reelaborar os arranjos de redes sociais de apoio, a começar com questões de migração e mobilidade.

A experiência de uma inclusão intensiva e imediata numa rede emergencial montada pelo Estado e pelas redes de atendimento de saúde com ela interconectadas inseriu as mulheres do interior, Selma e Ágata, numa caótica rotina de participação em viagens do Tratamento Fora do Domicilio (TFD), em ônibus e carros de prefeituras de municípios que, segundo as regras do funcionamento, ficam a mais de 50 quilômetros da Região Metropolitana. A complexidade das demandas de tratamento dos filhos e a intensa vontade de pesquisadores de saberem mais sobre a doença nova e desconhecida contribuíram para concentrar serviços em unidades já estruturadas no Recife. Apesar da vontade explícita de poder contar com centros de reabilitação com diversas terapias e serviços da complexidade necessária para lidar com convulsões, calcificações, deglutição, fisioterapia, oftalmologia e fonoterapia, obedecendo a todos os preceitos do cuidadoso 
e rapidamente adaptado manual de estímulo precoce pela Rede Estadual de Atenção à Saúde de Pessoas com Deficiência, era irreal imaginar que se poderia contar de imediato com tais instituições no interior, mais próximas das residências de Selma e Ágata.

No Recife, embora algumas instituições tivessem vários serviços, estes estavam dispersos em diferentes locais na cidade, dificultando a mobilidade das mães com os filhos. As instituições obedeciam a uma prioridade por capacidade instalada, reputações de competência e inserção no lucrativo mercado de serviços de saúde, mesmo tendo "braços" filantrópicos que aumentavam a sua clientela e a visibilidade social. A reputação e o número de pacientes que poderiam ser inseridos em pesquisas nas quais as instituições se envolviam faziam oscilar a oferta de serviços. Nas poucas instituições que tinham mais que um desses serviços, as agendas de marcação não costumavam permitir a realização de vários serviços em um só dia e num único local, com exceção dos dias de mutirões apoiados pela busca de dados de exames laboratoriais e clínicas associadas a pesquisas em instituições estruturadas, quando equipes ampliadas de pesquisadores e atendentes estavam presentes. O desgaste de sair de casa no escuro da manhã, num transporte precariamente aparelhado para transporte de pessoas com necessidades especiais, parar nas instituições onde descem e sobem outros, e voltar no escuro da noite para poder ter muitas vezes meia hora ou menos de atendimento efetivo e horas e horas de espera antes e depois é cansativo e desalentador (Canuto \& Silva 2020). Ter que fazer isso quase todos os dias da semana pesa muito. Com tudo isso, ainda era melhor que a opção de ficar numa das casas de apoio montadas pelos municípios para pessoas com necessidades por um tempo extenso, que se prolongava por mais de um dia. Estas casas, para elas, como mães que usavam transporte do TFD, além da sua relativa precariedade, não se adequavam a atendimentos tão prolongados quanto as limitações dos seus filhos precisavam.

Ágata, nos primeiros meses, esperava ter qualidade de serviços na cidade do Agreste onde residia. Afiliada à associação que protagoniza as demandas e os direitos, a União de Mães de Anjos, Ágata assume tarefas como intermediária-chave de ações da UMA com o objetivo de melhorar o atendimento no interior. O intuito era apoiar as mães cuidadoras e responder às suas necessidades já no período neonatal. A ausência do serviço, a lentidão da implantação e a avaliação negativa das mães do conhecimento e da qualidade de atendimento presentes nas suas cidades foram decisivos para provocar a decisão de Ágata de mudar com o marido para o Recife. 
Quando engravidou de novo depois de Sandra, Selma saiu do sertão, combinando com a mãe e o marido, e se deslocou para o Recife, onde se estabeleceu num apartamento alugado com os três filhos, ali nascendo o quarto filho. Ela explica:

E eu ainda estava esperando uma casa de apoio pra ver se eu ficava. Toda semana eu vinha, passava três ou quatro dias, pensei em arrumar um cantinho pra mim. Aí eu pensei, "É melhor ficar aqui mesmo, vou trazer os meninos, alugar uma casa maior e vou morar aqui, porque o outro vai nascer' ', e eu já tava me perguntando como vai ser a minha vida: "Ou esse menino não vai ter mãe...". Vim com eles porque eu já não tinha mais rotina com eles. [Ficou ]... puxadinha, não é? Mas para tudo dá um jeito. A casa fica assim, desse jeito. Botei ele na creche, o outro nasceu... (Selma, sem data em 2018, entrevistada por Luciana Lira).

No início da mudança, a mãe de Selma veio e ajudou, mas depois de poucos dias precisou voltar à cidade de origem para cuidar dos próprios filhos. Precisando, chamou o irmão, que veio "forçado" durante os primeiros quatro meses. Ela frequentou a AMAR todas as semanas nesse início e fez contato com a UMA. A rotina dos cuidados de três e, logo depois, quatro filhos dificultou frequentar os eventos das associações. Reduziu suas idas a oportunidades ocasionais, quando unia distração com o recebimento de materiais de higiene, leite e cestas básicas doados para distribuição entre as mães. A comunicação no grupo de WhatsApp da Associação para saber como andam as coisas para todas as mães de "micro" se mantém como canal importante de sociabilidade virtual e de informação sobre direitos. Vez por outra, sua mãe faz visitas curtas para ajudar no dia a dia na cidade, voltando logo para o sertão. O marido não se desapega do interior, mas também não consegue desenvolver um patrimônio particular com o serviço de transportes. Vem ao Recife umas quatro vezes por ano. Ela conseguiu organizar três voltas próprias com os filhos para passar alguns dias, reforçando as dimensões afetivas, lúdicas e solidárias não só dos seus laços com o interior, mas também os dos filhos. Mas o que mais caracteriza o cotidiano de Selma é depender de si mesma e cuidar dos filhos. Reclama não poder cuidar mais de si mesma. Fala que enfrenta situações constantes que exigem muita esperteza, bem como intermediações de responsáveis por atendimentos, para conseguir simplesmente sair de casa para tratar das demandas dos filhos e, em especial, de Sandra.

Ágata, que morava mais perto do Recife e numa cidade tamanho médio com boa infraestrutura, referência para saúde na região, continuou o vínculo forte com a presidente e fundadora da UMA no Recife. Não conseguindo 
trabalhar mais para ter renda própria, e já frustrada com a falta de serviços adequados para os bebês com microcefalia (incluindo Artur), cansada da viagem, num dia de mais uma consulta com a neuropediatra (também pesquisadora renomada), que a atende numa conceituada instituição no Recife, recebeu um convite da doutora que queria acompanhar o seu filho mais de perto. A doutora amiga sugeriu que ela poderia arrumar uma vaga para Artur ser atendido mais regularmente e disparou a pergunta induzidora: "ela toparia mudar pro Recife?". Como o marido, que ela sempre elogia pela atenção e a dedicação aos cuidados, estava presente na hora da consulta, foi ele quem respondeu que sim. Ágata estava de pleno acordo.

Entre a oferta da vaga na instituição no Recife e a sua efetivação houve um lapso de quase seis meses marcados por cansativas idas e vindas do Agreste para a capital. A cunhada de Ágata cedeu seu apartamento no Recife sem cobrar aluguel, possibilitando a sua vinda, do marido e dos dois filhos dele, os outros dois continuando com a avó materna no interior. A mãe de Ágata não costumava se oferecer para cuidar dos filhos que moram com Ágata, especialmente do Artur, por causa das limitações provenientes do SCZ. Como Ágata frisa sobre a colaboração da mãe, que cria os seus dois primeiros filhos:

Quando eu descobri a deficiência de Artur, a ajuda só veio mesmo do pai. A minha mãe mesmo, eu dizia: "mãe, fique com Artur pra mim sair, fique com Artur pra mim arrumar a casa e ter algum tempo livre." E ela dizia: "Não. Pode dar alguma coisa nele e eu não souber ajeitar ele. Eu prefiro ir arrumar a sua casa". A minha mãe sempre arrumava a minha casa e eu ficava com Arturzinho (Ágata, 08/11/2018).$^{10}$

A mudança de Ágata afastou-a de uma situação repetida que a incomodava. Mesmo que seus parentes fossem bem intencionados, ela sentia que não sabiam lidar com Artur, evitando-o, ou, quando melhor, com excesso de cuidado, "como se fosse boneco". Ela entendia isso como incompreensão e falta de solidariedade. Já estando no Recife, num apartamento distante de gente conhecida, estreitaram as relações dentro da família e diminuíram os contatos com outros parentes, fazendo com que a situação redefinida por Ágata fosse de só contar de fato com o marido e "as irmãs da luta", que são as outras mães que compartilhavam a sua experiência nos transportes, nas salas de espera, nas clínicas e, especialmente, na UMA.

Renata, que saiu muito jovem da zona canavieira, ficou morando com o marido depois de casar e ter o primeiro filho na parte de cima da casa da mãe. Das três mães, ela, mesmo se declarando claramente ser a única que se dedicava a todo o cuidado, também conta eventualmente com a colaboração 
das avós (tanto a sua própria mãe quanto a sogra) nos cuidados dos filhos, embora ela se estresse com a maneira com que se relacionam com Roberto. Respeita o fato de que elas têm as suas próprias obrigações. O freio no seu trabalho e na sua mobilidade veio com a combinação do nascimento próximo dos dois filhos, com realce para a proximidade das idades da filha mais velha e Roberto, acometido com a SCZ. O marido tem uma atitude firme quanto ao fato de que ela não deve voltar ao trabalho. Os rearranjos na moradia e nas relações entre parentes não foram tão significativos quanto os rearranjos das outras mães. Mesmo assim, ela dedicou a sua atenção aos problemas de mobilidade que sofria dentro da própria região metropolitana para ter acesso aos atendimentos. Para isso, ela reforça o apoio moral e emocional do marido e seu esforço de acompanhar ocasionalmente as idas aos espaços terapêuticos; cobra de sua mãe, que se dedica ao apoio quando pode, que esteja ainda mais presente; e conta com o apoio das associações de "mães de micro" e "mães de anjos" - a AMAR e a UMA. Ela valoriza a díade mãefilho, preservando o apelido para ela como "mãe de micro", ao remeter ao período da descoberta da epidemia quando a circunferência cranial era o fato unificador nas atividades e nas reivindicações delas, e também como "mãe de anjo", em que a referência à ligação emocional com o filho imprime ainda mais positividade aos vínculos espirituais entre corpo de mãe e corpo de filho.

\section{Recife, concentrador de serviços dispersos}

Nem mudar para o Recife, nem ser do Recife constitui uma solução suficiente para os enormes desafios de mobilidade que a cidade oferece. Qualquer residente que queira se deslocar para trabalho, estudo, compras ou documentações, independente de lidar com as demandas de terapias múltiplas e intensivas, experimenta este problema. Como em outras regiões metropolitanas, os serviços de saúde e assistência de maior complexidade e qualidade se concentram próximos ao centro da cidade. Apenas aparenta uma centralização com unidades de serviços próximas umas das outras, pois um exame mais detido mostra uma dispersão que dificulta ao usuário transitar a pé ou em transporte público entre elas. Cada instituição costuma ter reconhecimento em alguma especialização, complementando com alguns outros serviços que oferece. Quando se trata de demandas de múltiplas terapias e tratamentos, que sempre é o caso com afetados pela SCZ, costuma não haver um centro único de referência que tenha todos. 
Em razão do contexto da epidemia, acrescentam-se mais atividades de mutirões que combinam acesso de atendimento mais privilegiado e a realização de testes clínicos e coleta de outras informações nos corpos dos bebês para obter informações sobre a doença, num ambiente que favorece ratificação dos procedimentos de regulamentação farmacêutica (Scott et al. 2018b; Petryna 2009, 2011; Silva 2018). Isto força uma mobilidade interna na Região Metropolitana. Muitos experimentam os seus itinerários entre locais dispersos como uma peregrinação. Canuto e Silva (2020) acompanharam mãe e filha que moram num município na periferia da Região Metropolitana, mostrando os percalços (esperas, cobranças, discriminações, recusas de apoio, higienizações do filho, cargas de peso) em um período de 14 horas de mobilidade para realizar uma sessão de terapia de 30 minutos. A situação se complica quando há duas atividades marcadas, tornando-se uma operação ainda mais complexa para a família. O sofrimento do corpo do filho é compartilhado com a mãe e as pessoas eventuais que a ajudam.

Durante o período de emergência decretado pelo Ministério da Saúde do Brasil, entre fevereiro de 2016 e maio de 2017, acordos foram estabelecidos e recursos foram direcionados de modo a favorecer a descentralização dos serviços de saúde mais demandados pela nova condição patológica que se apresentara naquele momento, fazendo com que centros de reabilitação com diversos serviços aumentassem em número ao longo dos anos (Silva et al. 2017). A ideia era criar condições de estímulo às capacidades neurológicas e motoras mais afetadas no decorrer dos primeiros anos de vida, sem que para isso fosse preciso percorrer grandes distâncias. A ampliação dos centros de reabilitação no estado, como em todo Brasil, produz cifras de gestões que anunciam expressivas diminuições na distância para o centro mais próximo, mas a manutenção da qualidade e de equipes capacitadas destes centros é um desafio. É uma política que visa diminuir as exigências na mobilidade das famílias, mesmo que a concentração de serviços no Recife continue tendo uma força de atração para elas.

A concentração de recursos de infraestrutura, número de profissionais especializados, centros de formação e pesquisa em saúde, além dos equipamentos médico-hospitalares de grande e médio portes, públicos e privados, estabelecidos na cidade muito antes do surgimento da epidemia, acarretaram um magnetismo à cidade do Recife, atraindo mães e bebês todos os dias em busca de acesso a terapias, tratamentos e exames de alta complexidade, remédios e das especialidades clínicas mais escassas, como a neuropediatria. Os ônibus de TFD continuam circulando com afetados de SCZ e suas mães e outros pacientes do interior. O transporte coletivo especializado para pessoas com limitações de mobilidade se restringia a pessoas em cadeiras de roda, e para terapias marcadas (não para consultas). 
A realidade que se apresenta para as mães é a do domínio de atendimentos que se reporta a lógicas institucionais. Os itinerários terapêuticos constroem noções de maternidade em relação aos filhos (Scott et al. 2018b) nos vários serviços descentralizados no próprio Recife, respondendo fortemente às condições estabelecidas de instituições atuantes há décadas em contratar pessoas capacitadas, angariar serviços e acumular recursos. Os acordos destas instituições aproveitam capacidades profissionais já reconhecidas de atendimento e pesquisa, permitem crescimento emergencial em nome de poder melhor conhecer as características, as causas e as consequências da Síndrome. Visa bem mais do que apenas atender aos pacientes, pois agrega encontrar meios novos de prevenir e tratar a doença antes desconhecida. Quem tem que ter mobilidade é a fonte de informações que ampliam o prestígio da instituição, seja ele o paciente, sua mãe ou as pessoas que os apoiam. Os experimentos viajam para longe, as mães e as crianças se deslocam constantemente, e as instituições se expandem.

O resultado é fisioterapia, fonoaudiologia, oftalmologia, neurologia, exames clínicos em lugares distintos, e as mães correndo atrás da autorização para poderem andar gratuitamente nos ônibus pouco adaptados às suas necessidades. Têm que comprovar a pobreza com uma renda de menos que um quarto de salário mínimo por pessoa da família no Cadastro Único para receber o cartão que permite transporte gratuito quase exclusivamente quando acompanhado pelo bebê/criança, o que se dá diante dos funcionários de transportes fiéis às diretrizes de políticas de mobilidade. Mais de três viagens ao ano sem o filho deficiente acompanhando, perde-se o direito. Transforma-se em uma reificação da responsabilidade exclusivamente materna para cuidado (Scavone 2004), que combina a supervalorização da maternidade com o aumento do peso social que passa a ter, ao mesmo tempo em que torna a maternidade uma moeda de troca na busca de direitos.

Os mesmos dados do Cadastro Único são computados para se ter acesso ao Benefício de Prestação Continuada - BPC, que abrange 63\% das inscritas (Barbosa et al. 2020:6). A renda complementar, de um salário mínimo, é para amenizar os altos custos de alimentação, transporte e higiene das suas crianças, sem pensar em arcar com custos associados à mobilização eventual de amigas e parentes para auxiliar, levando e manuseando a grande quantidade de material necessário para os cuidados diários e dispostos a contribuir para apaziguar os bebês, conversar e brincar durante longas horas de espera. É um valor muito abaixo para se atenderem a tantas demandas. Em conformidade com as observações de Silva (2018), é uma precariedade oportuna para a ciência, muito bem aproveitada no mercado de produtos e serviços de saúde. 
Os mutirões, associados parcialmente a recursos de pesquisa (ver descrição em Scott et al. 2018a), são as ocasiões em que se unem profissionais e serviços de locais de atendimento com reconhecidas capacidades de agir com outros profissionais e trabalhadores de diferentes lugares voltados à atenção aos pacientes e à pesquisa, oferecendo vários serviços de análises e de atendimento. Em vez de apenas procurarem os seus próprios locais e os horários regulares de atendimento, as mães são convocadas a comparecer com os seus filhos, mobilizando-se para estarem presentes neste único espaço valioso, disponível num só dia. Elas têm o cuidado de informar a razão de se ausentarem de serviços regulares marcados para a mesma hora para não se colocarem em risco de desligamento por faltas. Mutirões são atraentes para mães por simultaneamente diminuírem a necessidade de andar tanto, por darem acesso a compensações especiais, como refeições e doações, e desenvolverem a noção de que seu filho está fornecendo informações que ajudarão, primeiro, a entender a própria situação com mais completude e propriedade e, segundo, a fornecer informação para que, através da pesquisa, outras pessoas no futuro talvez tenham que sofrer menos com as consequências da doença, inclusive generalizando para os problemas de desenvolvimento comuns em diversas situações de deficiência.

Lamentavelmente, tais informações geradas nos mutirões, com muito mais frequência ali do que nos outros atendimentos que costumam ter, não são entregues nas mãos das mães. Pesquisadores e profissionais, mesmo quando ressaltam a importância de essas famílias receberem os resultados dos exames, em geral não encontram maneiras de retornar os resultados, tão importantes para as suas pesquisas, às mães interessadas nos cuidados dos seus filhos com deficiência por serem informações mais completas. É nos mutirões também que ocorrem repetições de entrevistas com "as mesmas perguntas de sempre!", realizadas por assistentes de pesquisa que apenas têm contato com elas nessa hora. A experiência do mutirão, tão promissora, contribui para um desalento - somente facilitaram o acesso a muitos serviços e exames num único local porque estão pesquisando, não exatamente para diminuir as dificuldades de atendimento e mobilidade de mães e filhos.

Cada local visitado é mais um conjunto de documentos próprios e formulários preenchidos, e a tensão da incerteza se o atendimento terá continuidade. A repetição de altas pelas instituições deixa as mães ressabiadas. Temem que os locais frequentados achem não poderem oferecer mais nada aos filhos porque o progresso é lento e atrapalha a consecução de metas institucionais de "realização de atendimentos que atingem resultados". Como diz Ágata, "cuidado com tal instituição, vai te dar uma rasteira". Cada desistência institucional, por mais que desanime, 
também alimenta a vontade das mães de insistirem na positividade de sua dedicação, de sua não desistência, de seu amor incondicional. Configura-se o discurso de que os filhos precisam de terapias, mas que não são "doentes", e isto contribui para gerar tensão nos seus ambientes não biomédicos, nas suas relações na vizinhança e na própria família. A diferença entre doença/ deficiência é muito relevante, pois a comemoração da alta como uma cura da doença, frequente em outros contextos de epidemia de doenças curáveis, é bem diversa da consciência que têm as mães de haver uma deficiência que afetará todo o modo de estar no mundo do seu filho e de si mesmas. Quando a epidemia passar, o desenvolvimento do filho continuará sendo fator premente na vida da família que cuida.

A indignação de Selma, Ágata e Renata, reforçada por toda esta superimersão subordinada aos domínios de serviços e de conhecimento de saúde, vai na direção de seus vizinhos e familiares, que não parecem capazes de tratar os bebês/crianças como pessoas que têm seu "modo corporal de estar no mundo" como uma construção social, e não um modo biomédico no sentido dos problemas vividos:

[...] todo mundo ao meu redor tratava ele como se ele fosse um boneco de vidro e era o que eu detestava. [Teus parentes? Não pegavam ele?] Tinham medo de pegar... o jeito de pegar... "Ah, como é que eu pego essa criança?". "Igual a um bebê normal, minha filha, pegue aí de todo jeito, do jeito que pega...". Eu falava assim, né? E as pessoas até chegaram a dizer assim, que eu tava saindo pouco na rua com ele porque eu tinha vergonha dele, por causa da deficiência dele, que para os ignorantes não é deficiência, é doença, né? [A minha sogra disse]: "Mas não pode deixar ele chorando desse jeito não, porque ele é doente. E eu disse: "Ele não é doente não!". Aí eu disse: "Ele não é doentinho não". Doente é quem tá lá no hospital, ele tá no hospital? Ele tá gripado? Não tá. Ele tá sentindo dor? Não tá. Então ele não tá doente. Ele tem uma deficiência. É muito diferente de ser doente. Aí ela se fechou e foi embora. Hoje, sim, eu até evito mais de ir para a frente da minha casa, mas por causa disso, né? (Renata, 07/2017). ${ }^{11}$

A última vez que eu estive no interior, na casa da minha mãe, percebi que estava ali a família toda reunida, meus irmãos, meus filhos, os filhos do meu irmão, os filhos da minha irmã. Tinha outras pessoas da família, então sempre eu fico num canto com Artur. Eu percebi que ninguém chega assim em Artur, até os próprios irmãos mais velhos. Já teve primo de dizer assim: "Ôxe, com Artur não pode brincar porque ele é doentinho. Ele fica assim com a cabeça". Os primos de 9, de 8 anos! Teve um dia que eu fui grossa com eles. Eu disse: “Ele não é doente! Doente é você. Você vai se tornar um adulto com a cabeça 
doente!". Estou sempre transitando [com ele], dou banho, dou comida, sempre estou com ele e à noite também. Dorme comigo porque, como ele não se mexe, eu fico trocando ele de posição. Entendeu? Então, assim, é 24 horas do dia dedicadas a ele. Se alguém chegar e disser que ele está pesado, que ele é um inútil, alguma coisa, isso vai me doer profundamente. E vem mais da família. (Ágata, 08/11/2018). ${ }^{12}$

[...] Ninguém convive, né? Mas assim quando eu tô lá, eles querem ver a menina, pegar, mas eles não têm a noção que eu tenho de que Sandra não é uma pessoa doentinha. [Até o meu marido] diz: "doentinha", "bichinha"! Eu digo logo: "Ela não nasceu doentinha, não". Eles não têm noção que ela é uma criança especial, tem que tratar de maneira correta, isso acaba... Não vai demonstrar, não é legal, porque se eu for comprar briga com cada palavra errada... (Selma, 2018). ${ }^{13}$

A dedicação e a busca de direitos têm efeitos na formação de redes de apoio e na efetivação das terapias. Singularizam a mãe e uma ou outra parente como dedicadas, e as distanciam dos outros, o que ocasiona a sensação de enfrentamento de um preconceito embutido e pouco consciente até de pessoas mais próximas, coisas que não esperaria de "família". Contribui para o isolamento das mães e a repetição de que para cuidar "sou eu e eu mesma", fazendo depois um elogio a mais alguém, bem particularizada (sobretudo a mãe ou a irmã), que "ajuda muito e faz o que pode", com o reconhecimento de que está sendo difícil para esta pessoa ajudar tanto quanto possível. Mesmo quando não se queixa da pouca ajuda, chegando a dizer que parentes e pessoas próximas auxiliam, percebe-se a constatação de que ninguém pode se dedicar tão plenamente que consiga resultar num verdadeiro alívio para as próprias mães. Diminuem-se expectativas de ações de parentes, justamente por se saber que as demandas são tão grandes que, mesmo para as pessoas mais próximas, vai parecer uma relação marcada por sentimentos de caridade ou pena que não cabem plenamente no vínculo caracterizado como familiar. Ou seja, estreita-se mais ainda a rede de apoio familiar, mesmo quando este apoio se apresenta com múltiplas facetas. Somente nestas três narrativas de experiências, vimos familiares e pessoas próximas abrigando filhos de outros casamentos, visitando em tempos de intervenções médicas e hospitalares, cuidando dos outros em casa, ajudando na arrumação da casa, pegando os outros filhos na escola, cozinhando, concedendo apartamentos para morar, transportando quando possível, pagando planos de saúde etc. 
Ter um marido que ajuda em algumas dessas coisas é outra situação. A simples presença é quase inesperada e, quando ele está presente, é tido como grande companheiro que compartilha o que pode, ao mesmo tempo em que é mais um familiar com limitada capacidade. Não se espera dele que saiba cuidar da forma desejada, por exemplo, como a mãe ou a irmã, cujo apoio é naturalizado e avaliado com um ar crítico mais contundente. Os filhos, irmãos do bebê, têm as suas rotinas fortemente influenciadas pela presença do irmão com SCZ, e isto preocupa as mães que às vezes sentem que estão cobrando demais a participação deles, às vezes que não estão conseguindo ser "mães deles" também. Mas todas estas ajudas e limitações, reconhecidas como parte de relações familiares e entre parentes próximos, mas contrastantes em intensidade, não desfazem a sensação das mães de estarem sozinhas.

Tais sensações são evidências de que as relações familiares agem como fonte de subordinação de mulheres dentro do grupo familiar, marcado historicamente pela distinção entre esferas pública e privada. Seguindo a análise histórica de maternidade e subjetividade de Badinter (1985), feministas há tempo insistem que a própria família é uma unidade dividida (Ramos 2009; Firestone 1970), cuja invocação idealizadora de unidade aprisiona e subestima o valor do trabalho feminino. São colocados em evidência aspectos produtivos do trabalho doméstico, entre os quais, o cuidado (Bruschini \& Madeira 1983; Abreu \& Sorj 1993; Scavone 2004). No caso dessas mães, algumas das quais têm experiência de cuidar da casa de outras pessoas, o trabalho de cuidado que pode se estender a espaços globalizados e às casas dos outros, como descrito por Helena Hirata (2016), Hirata e Guimarães (2002) e Guimarães et al. (2011), torna-se inimaginável, e precisou ser cortado, já que aquele ao qual se dedicam na sua própria casa não permite acréscimos.

O imbricamento de família e maternagem como bandeiras morais e guias de linhas de vida não tem escapado à atenção de uma crescente parcela de mulheres-mães cuja relação com os serviços e o Estado se torna uma luta a mais, preponderante, ultrapassando o diálogo e a inserção em redes de benefícios, formando um elenco de confrontação que clama que o Estado deva se reconfigurar de acordo com as demandas, o que causa sofrimento diante da insensibilidade da resposta. São diversas as etnografias que centram seu olhar nas relações entre mães e Estado e na figura política das mães nessa relação. Quando o Estado se apresenta com uma face explicitamente violenta, realizando desaparecimentos e assassinatos, uma arma que se mostra eficaz é a indignação através de uma organização, a divulgação de protestos e a criação de imagens delas como mães que perderam os filhos. Aproveitam 
qualquer oportunidade para frisar "a relevância do lugar simbólico da maternidade e, em especial, as conexões entre dor pessoal, dor moral e dor política que se produzem nessas condições dramáticas" (Vianna \& Farias 2011:89). O evento dramático de perder um filho por causa de violência institucional difere do evento dramático de ver nascer um filho deficiente, pois a agência do Estado na perda, mesmo quando presente, é menos evidente. A relação com as mães se dá principalmente através de setores simbolicamente mais femininos do Estado e mais caracterizados como de "atenção" e de "cuidado", com variados graus de (in)sensibilidade. Nelvo (2020) mostra uma mãe de deficiente que enfrenta as formas multifacetadas do Estado de se relacionar com as mães de uma maneira burocraticamente indiferente, humilhante e absolutamente invasora do tempo materno. $\mathrm{O}$ evento da epidemia de Zika, que resultou no nascimento de filhos com deficiências, contribui para uma rápida coletivização das demandas, pela quantidade de "fios de vida" afetados, adensando a malha e oportunizando a criação de mais uma instância clara de politização da maternidade.

A solidariedade se constrói com as outras mães, encontradas nas andanças de clínica em clínica, dentro dos transportes especializados quando se tem, e nas associações cujas atividades lúdicas e festivas criam horas de distração com o reconhecimento da importância da inclusão dos filhos no ambiente. UMA e AMAR reivindicam, para melhor tratamento na prática e na legislação, o direito a benefício e à pensão, e a expansão dos locais de acolhimento. Estas são, como Ágata as batizou, "as irmãs da luta", que efetivamente compartilham a experiência de cuidar de um filho portador da Síndrome Congênita de Zika. Na internet, cada uma delas tem os seus grupos particulares de família e amigos no WhatsApp e, quando é adepta, posta no Facebook e no Instagram, sabendo que as colegas podem ver mais nesses espaços. O grupo de mães de bebês com SCZ da Associação é um grupo especial, no qual se pode receber ajuda nos pleitos de direitos, mas também em que experiências podem ser compartilhadas, mandar fotos que comunicam carinho, descobrir onde haverá festividades, doações e atendimentos, planejar atividades em nome dos filhos com regularidade, sabendo que será compreendida por se tratar de uma mãe que tem uma experiência paralela, ou mesmo fortalecer a luta para uma pensão vitalícia, como foi assegurada na medida provisória 894 de 2019 (Matos et al. 2019). Uma associação formada em torno das pessoas atingidas por um vírus, no processo de lutar pelo reforço a esta bioidentidade (Rabinow 2004; Rose 2013), não faz apenas intensificar oportunidades de atendimento e terapia, mas também consegue uma participação maior nas diversas instâncias de afirmação de cidadania (Cornwall \& Shankland 2008). 
Na cidade, as redes familiares, ainda importantes, se estreitam e tendem a diminuir em número e frequência de interações, com mães e maridos, e às vezes irmãs, destacando-se tanto pelo que fazem quanto pelo que não fazem. A inserção numa rede complexa de instituições terapêuticas e serviços governamentais dispersos oferece uma multiplicidade de contextos nos quais a relação com médicos, profissionais e funcionários se torna quase tão cotidiana quanto a da própria casa. Mas estas mesmas redes repetidamente se distanciam simbolicamente das mães e dos filhos quando a formalidade, as limitações dos serviços e a pesquisa de informações sobre a patologia os invisibiliza enquanto sujeitos. Amplia-se a interação, difícil de manter presencialmente pelos constrangimentos de tempo, mas facilitada pela comunicação através da internet. Nas associações, as outras mães em condições semelhantes viram irmãs, não somente na sociabilidade e por comungarem percepções menos discriminatórias dos filhos que vivem com as sequelas da Síndrome, mas também por estarem procurando ludicidade, doações, tratamento e atendimento melhores e, sobretudo, direitos. É um ambiente simbolizado por referências a relações familiares, absolutamente fundamental para negociar direitos. Como falou a presidente da Associação Famílias de Anjos do estado vizinho numa entrevista no Instagram sobre as horas de emergência: "nessa hora, sou advogada, enfermeira, fisioterapeuta, psicóloga, mas, sobretudo, avó de todas as mães e crianças daqui" (Oias 12/04/2020).

Mobilidade e família no contexto da epidemia: famílias, corpos, deficiência e direitos

A mobilidade é um meio para as mães e seus filhos reorganizarem as suas redes de relações e acessarem direitos essenciais a serviços de saúde e outros serviços. Tem o poder de contribuir fortemente para a inclusão das mães como cidadãs cuja dedicação aos filhos reforça os seus direitos. Reorganizar relações familiares de acordo com mudanças de residência ocasionadas por alguma necessidade sentida é prática corriqueira para famílias. Mudar de residência para ter melhor acesso a centros de reabilitação especializados é um peso assumido pelas mães na ausência de serviços próximos às suas casas. Fugiram de uma mobilidade, de transporte TFD ou outro meio, quase exclusivamente feminina, que lhes roubava tempo, dinheiro e interação com a família. Entraram em outra mobilidade cotidiana a dos serviços dentro da Região Metropolitana - que pouco alivia o dispêndio e o desgaste para seus usuários. A mobilidade é fundamental, mas ela traz 
problemas aos serviços de saúde e outros serviços relacionados, cujos esforços de manter cadastros atualizados e regimentar o uso de meios de transporte (além de outros serviços), e ao mesmo tempo serem sensíveis à composição familiar, esbarram em rigidez de normas e priorização de outros objetivos. Estes objetivos criam respostas através de práticas que colocam em evidência a fragilidade e a dispersão dos serviços e sua capacidade de incentivar o sofrimento por mobilidade. Quando havia a necessidade de informações sobre características da doença para pesquisadores, prestadores de serviços de saúde, terapeutas e a indústria de medicamentos, os mutirões facilitavam o acesso das mães com as crianças aos outros domínios. No entanto, ao serem obtidas as informações, tais oportunidades esmaecem (Petryna 2009; Silva 2018; Silva et al. 2017).

Mães não são somente cuidadoras e, ao realçarem a dedicação ao seu filho, convertem o materno-infantil de saúde na imagem de um corpo unido de mãe e filho, demandando serviços dos domínios de atendimento e de conhecimento no campo da saúde. Simbolicamente, a força centrípeta dessa união de corpos provoca decisões de mudar de residência e de usar constantemente meios de mobilidade urbana, e seleciona, organiza e aciona redes de relações na família capazes de contribuir para a saúde da criança.

A relação familiar aproxima e cria unidade enquanto afasta quem não compartilha da problemática e se orienta por noções de gênero e de geração. Mulheres de gerações anteriores ajudam suas filhas e noras na prática de cuidar, mesmo que seja seletivamente, nas práticas para as quais se sentem habilitadas, resguardando-se da plena dedicação ofertada aos seus netos pelas filhas e noras.

A singularidade da experiência de SCZ, que remeteu todas as envolvidas a uma intensa interação prolongada no campo da saúde, promoveu a inclusão de irmãs da luta nesta rede familiar através de associações de mães montadas e dirigidas por mães nas mesmas condições de organização familiar. Mesmo em face da diversidade de idades, formou-se uma unidade na mesma geração em torno da relação mãe-filho. Acrescenta-se um elemento de cidadania e busca de direitos próximo de uma moralidade familiar, sem ignorar o fato, aprendido repetidamente na experiência de viver um itinerário terapêutico e de busca de serviços, que o que incentiva as instituições, os pesquisadores e mesmo os legisladores requer conhecimento ou compreensão de outras regras, pois, por mais próximos que estes sejam, estão labutando em domínios que não se orientam prioritariamente pela mesma lógica. O domínio da relação familiar, que ressalta a qualidade dos vínculos sociais simbolicamente reforçados por referências a relações familiares, produz o contraponto que valoriza as suas demandas e os seus direitos. 
Resumindo, mobilidade no Recife é imposta às mães, embora seja muito pouco facilitada, mesmo que incorporada a algumas demandas de serviços. As variadas redes sociais nas quais se operava antes de ter um filho com deficiência são reduzidas a algumas pessoas proximamente relacionadas, cujos esforços, embora elogiáveis, nunca são suficientes para suprir os enormes esforços das mães. A construção de coletivos de mães com fortes lideranças (também mães de filhos com deficiência), na AMAR e na UMA, é biorreferenciada também, combinando atenção à melhoria do atendimento e das políticas nas suas diversas facetas com a busca da criação de espaços mais humanizados ou o acesso a benefícios e pensões. Quando o filho é deficiente, e não doente, mesmo que a deficiência tenha resultado de uma doença, o leque de domínios nos quais se possa inserir se amplia e a sua identificação como cidadão se sobrepõe àquela de alguém acometido por uma doença (Diniz 2007; Scott 2020; Matos et al. 2019). Os espaços de negociação de direitos ultrapassam aqueles dos favorecidos pela área de saúde.

As mães seguem ameaçadas se faltarem a compromissos marcados devido às dificuldades de mobilidade. Cada espaço de atendimento, de acordo com as suas especializações, reforça uma escolha da parte do corpo a ser atendida na hora e elabora um significado bioidentificado específico que se molda diferentemente de acordo com a interação bebê-mãeespecialista. A circulação de conhecimento entre o especialista e a mãe, selada na prática com a vivência da reação do corpo do filho, torna a mãe portadora de um sistema de significação médica, revalidado ou desmentido, na prática cotidiana. Mesmo que haja pessoas que acompanhem nos cuidados, narrativamente as suas sensibilidades não conseguem se igualar às sensibilidades das mães, unidas com os filhos. Quando elas insistem que os filhos não são doentes, são deficientes, estão defendendo a sua própria capacidade de cuidar e sentir ao mesmo tempo em que estão resistindo à discriminação e extrapolando as delimitações mais estreitas dos espaços de negociação.

As suas histórias são altamente singulares e confluentes. Elas negociam a participação de familiares, parentes e amigos e as transformações das redes de apoio, e também os deslocamentos residenciais; fazem avaliações sobre os apoios recebidos, a organização e as falas e as compreensões muito variadas sobre seus filhos. Vivem uma peregrinação entre especialistas que exige foco nas partes específicas dos corpos e das formas de intervir nesses corpos, segundo um conhecimento em construção sobre uma nova doença informada pela sua relação com outras sequelas de doenças bem conhecidas e de sua inserção na condição de deficiência. 
Mulheres que se sentem limitadas na sua mobilidade, que vivem uma contraditória experiência de confinamento nos meios de deslocamento na cidade, fazem desta mobilidade uma forma de reorganização da família, que estabelece como um corpo múltiplo a mãe e o filho deficiente, corpo este visto através de variadas perspectivas pelos integrantes dos domínios nos quais se insere. A família fica imersa em terminologias, tecnologias e compreensões medicalizadas e burocratizadas da vida, cujas novas redes de entretenimento e distração não conseguem ser separadas das redes de mobilidade, mobilização e reivindicação. Os esforços das próprias mães - com as suas habilidades de compreensão e representação particulares do corpo do filho - trabalham em coligação com associações, nas quais, ao quererem também cuidar das cuidadoras, fazem esse ato se tornar tão inseparável do cotidiano quanto o corpo do filho é inseparável do corpo da mãe. As irmãs de luta tão prezadas por elas são as pessoas incorporadas a essa intensificada relação "familiar" de terem experimentado trajetórias semelhantes. Com muito sacrifício, dificuldade de mobilidade imposta a elas e reorganização de redes de relações, descobriram que é viável continuarem juntas como "irmãs" que são "mães" para sensibilizar os agentes de serviços de atendimento e alguns pesquisadores, e também os diversos espaços de negociação de direitos de cidadão que lidam com suas demandas que estejam merecendo consideração.

Recebido em 14 de maio de 2020

Aprovado em 12 de dezembro de 2020

\section{Russell Parry Scott}

Antropólogo, professor titular da antropologia da Universidade Federal de Pernambuco no Programa de Pós-Graduação em Antropologia, fundador e coordenador do Núcleo de estudos FAGES - Família, Gênero e Sexualidade (https://www.ufpe.br/fages); Pesquisa as relações entre a esfera doméstica e a esfera pública e poder em ambientes rurais e bairros populares urbanos; famílias, migrações, projetos de desenvolvimento, gênero e saúde pública, bem como a história das antropologias. Autor de Famílias Brasileiras: Poder, Desigualdades, Solidariedades (2011); Negociações e resistências persistentes: agricultores e a barragem de Itaparica num contexto de descaso planejado (2009); Práticas Sociais no Epicentro da Epidemia do Zika (2020).

https://orcid.org/0000-0003-2274-9859

E-mail: rparryscott@gmail.com 


\section{Notas}

1 A compreensão de famílias e a sua relação com saúde deriva em parte da abordagem de Scott em outras obras (2011a, 2011b).

2 Dados de abril de 2019.

3 Projeto desenvolvido pelo FAGES (Núcleo de Família, Gênero, Sexualidade e Saúde) da Universidade Federal de Pernambuco. A pesquisa conta com o apoio da CAPES (8888.130742/2016-01), do CNPq (440411/2016-5), DECIT-MS, sob o título "Action Ethnography on Care, Disability and Health Policy and Administration of Public Service for Women and Caretakers of Zika virus affected Children in Pernambuco, Brazil, tendo o apoio de FACEPE/Newton Fund (APQ 0553-7.03/16).

4 Os três docentes e uma doutoranda foram os únicos a atravessar o período todo de novembro de 2016 a outubro de 2020: Parry Scott, Marion Teodósio de Quadros, Ana Claudia Rodrigues da Silva e Fernanda Meira de Souza. As pesquisadoras doutoras passaram os primeiros três anos: Luciana Campêlo de Lira, Silvana Sobreira de Matos. Outros bolsistas (cinco mestrandos, sete bolsistas de iniciação científica e três técnicos) participaram em interstícios menores.

5 Soraya Fleischer integra a equipe de "Etnografando cuidados" e tem pesquisa própria sobre as mães do Zika no mesmo período. Os seus relatos e as suas observações e da sua equipe complementam o trabalho aqui descrito.

6 Permissão do Comitê de ética da UFPE: 06 de abril (submetido 15 de março) CAAE: 65741717.0.0000.5208, e Secretaria Estadual de Saúde - PE aprovação 02/08/2017.

7 No texto de Scott (2020) sobre prioridades na epidemia, há um detalhamento desses domínios, diferenciando como, na prática de cuidar, dedicação, sacrifício e competência constroem e são construídos pela valorização de diferentes especificidades relacionais e temporais em cada um deles.

8 Uma excelente análise das práticas institucionais na administração de serviços se encontra no binômio gestão e gerir em Souza Lima (2002). Herzfeld (1993) mostra o quanto estas práticas podem contribuir para a produção social da indiferença diante de cidadãos (e o inverso, quando, em algum evento, praticantes fogem da limitação estrita dos procedimentos requeridos da burocracia).

9 Nelvo emprega a noção de "vidas possíveis de serem vividas" em acordo com Butler (2018).

10 Entrevistada por Luciana Lira, Fernanda Meira e Silvana Matos.

11 Entrevistada por Luciana Lira e Fernanda Meira.

12 Entrevistada por Luciana Lira, Fernanda Meira, Silvana Matos.

13 Entrevistada por Luciana Lira. 


\section{Referências bibliográficas}

ABREU, Alice Rangel de Paiva; SORJ, Bila (orgs.). 1993. O trabalho invisível: Estudos sobre trabalhadores em domicílio no Brasil. Rio de Janeiro: Rio Fundo.

ADAMS, Richard N. 1975. Energy and structure, a theory of social power. Austin: Univ. of Texas.

ALBUQUERQUE, Maria de Fatima Pessoa Militão de; SOUZA, Wayner Vieira de; ARAÚJO, Thalia Velho Barreto; BRAGA, Maria Cynthia; MIRANDA FILHO, Demócrito de Barros; XIMENES, Ricardo Arraes de Alencar; DE MELO FILHO, Djalma Agripino; BRITO, Carlos Alexandre Antunes de; VALONGUEIRO, Sandra; MELO, Ana Paula Lopes de; BRANDÃOFILHO, Sinval Pinto; MARTELLI, Celina Maria Turchi. 2018. “Epidemia de microcefalia e vírus Zika: a construção do conhecimento em epidemiologia". Cadernos de Saúde Pública, v. 34, n. 10, e00069018.

AYRES, José Ricardo de Carvalho Mesquita. 2004. "Cuidado e Reconstrução das Práticas de Saúde". Interface: Comunicação, Saúde e Educação, v. 8, n. 14:73-92.

BADINTER, Elizabeth. 1985. Um amor conquistado: o mito do amor materno. 8. ed. Rio de Janeiro: Nova Fronteira.

BARBOSA, Fátima Maria Ferreira; REIS E SILVA, Joelson Rodrigues; SAMICO, Shirley de Lima. 2020. "Vulnerabilidades e desproteção social das famílias com casos confirmados de Zika Vírus: os dados revelados através do Cadastro Único para Programas Sociais". In: Parry Scott; Luciana Lira \& Silvana Matos (orgs.), Práticas Sociais no Epicentro da Epidemia do Zika. Recife: Edufpe. Cap. 02:1-14 (ebook).

BONET, Octávio. 2014. "Itinerações e malhas para pensar os itinerários de cuidado. A propósito de Tim Ingold". Sociologia \& Antropologia, v. 04 (02):327-350.

BOURDIEU, Pierre. 1992. O poder simbólico. Lisboa: Difel; Rio de Janeiro: Bertrand.

BRUSCHINI, Cristina Aranha \& MADEIRA, Felícia Reicher. 1983. "A família, a estrutura social e as formas de participação na produção social". Cadernos Ceru, USP/São Paulo, 18:147-186.

BUTLER, Judith. 2018. Corpos em aliança e a política das ruas: Notas para uma teoria performativa de assembleia. Rio de Janeiro: Civilização Brasileira. CANUTO, Thaiza Raiane Vasconcelos \& SILVA, Ana Cláudia Rodrigues da Silva. 2020. "Vidas em trânsito: deslocamentos no contexto da Síndrome Congênita do Zika (SCZ)". In: Parry Scott; Luciana Lira \& Silvana Matos (orgs.), Práticas Sociais no Epicentro da Epidemia do Zika. Recife: Edufpe. Cap 8:1-23 (ebook).

CARSTEN, Janet. 2004. After Kinship. Cambridge: Cambridge University Press.

CORNWALL, Andrea \& SHANKLAND, Alex. 2008. "Engaging Citizens: Lessons from Building Brazil's National Health System". Social Science \& Medicine, 66 (10):2173-84.

DINIZ. Débora. 2007. O que é deficiência? São Paulo: Brasiliense. 2016. Zika: Do Sertão nordestino à ameaça global. Rio de Janeiro: Civilização Brasileira. 
FERNANDES, Camila. 2018. "O tempo do cuidado: batalhas femininas por autonomia e mobilidade". In: Everton Rangel; Camila Fernandes \& Fátima Lima (orgs), (Des)prazer da norma. Rio de Janeiro: Papéis Selvagens. pp. 297-320.

. 2017. Figuras da causação: sexualidade feminina, reprodução e acusações no discurso popular e nas políticas de Estado no Rio de Janeiro. Tese de Doutorado, Museu Nacional, Programa de Pós-Graduação em Antropologia Social, UFRJ.

FIRESTONE, Shulamith. 1970. The Dialectics of Sex: The case for Feminist Revolution. New York: Bantam.

FLEISCHER, Soraya. 2018. "Cenas de Microcefalia, de cuidado, de antropologia". Cadernos do Campo, Recife, v. 27:118-131.

FLEISCHER, Soraya \& LIMA, Flávia (orgs). 2020. Micro: contribuições da antropologia. Brasília: Athalaia.

FONSECA, Cláudia. 2007. "Apresentação - de família, reprodução e parentesco: algumas considerações". Cadernos Pagu, 29:9-35.

FREIRE, Lucas de Magalhães. 2019. A gestão da escassez: uma etnografia da administração de litígios de saúde em tempos de "crise". Tese de Doutorado, Museu Nacional-PPGAS, UFRJ.

GIDDENS, Anthony. 1993. A transformação da intimidade: Sexualidade, amor e erotismo nas sociedades modernas. São Paulo: Editora da Unesp.

GUIMARÃES, Nadya Araújo; HIRATA, Helena Sumiko \& SUGITA, Kurumi. 2011. "Cuidado e cuidadoras: o trabalho de care no Brasil, França e Japão". Sociologia \& Antropologia, 1 (1):151-180.

HERZFELD, Michael. 1993. The social production of indifference. Chicago and London: The University of Chicago Press.

HIRATA, Helena, 2016. "O trabalho de cuidado: comparando Brasil, França e Japão". SUR, v. 13, n. 24:53-64.

HIRATA, Helena \& GUIMARÃES, Nadya Araujo (orgs.). 2002. Cuidado e cuidadoras: as várias faces do trabalho do care. São Paulo: Atlas.

LIRA, Luciana Campelo de; SCOTT, Russell Parry \& MEIRA, Fernanda. 2017. "Trocas, Gênero, Assimetrias e Alinhamentos: experiência etnográfica com mães e crianças com síndrome congênita do Zika". Revista Anthropológicas, Ano 21, n. 28 (2):206-237.

MATOS, Silvana; QUADROS, Marion Teodósio. \& SILVA, Ana Claudia Rodrigues da. 2019. "A negociação do acesso ao Benefício de Prestação Continuada por crianças com Síndrome Congênita do Zika Vírus em Pernambuco". Anuário Antropológico, v. II:229-260.

MOL, Anne Marie. 2002. The body multiple: ontology in medical practice. London: Duke University Press. . 2008. The Logic of Care. Health and the Problem of Patient Choice. New York: Routledge.

NELVO, Romário. 2020. Cotidianos, Família e o Trabalho do Tempo: Dobras políticas no ativismo da maconha medicinal no Rio de Janeiro. Tese de Doutorado, Museu Nacional-PPGAS, UFRJ.

OIAS. Observatório de Impactos Ambientais e de Saúde. 2020. "Vulnerabilidade Social no Contexto da Pandemia do COVID-19: Os desafios das famílias de Crianças com a Síndrome Congênita do Zika". Apresentação virtual bit.ly/saudeoias. Maceió: PPG-SOTEPP - Sociedade, Tecnologias e Políticas Públicas. Acesso em 12/05/2020. 
PETRYNA, Adriana. 2011. "Experimentalidade: Ciência, Capital e Poder no Mundo dos Ensaios Clínicos". Horizontes Antropológicos, Ano 17, n. 35:127-160. jan./jun. . 2009. When experiments travel: clinical trials and the global search for human subjects. Princeton: Princeton University Press.

RABINOW, Paul. 2002. Antropologia da razão. Rio de Janeiro: Relume Dumará.

RAMOS, Daniela Peixoto. 2009. "Pesquisas de usos de tempo: Um instrumento para aferir as desigualdades de gênero". Revista de Estudos Feministas, Florianópolis, v. 17, n. 3:861-870, dez.

ROSE, Nikolas. 2013. A política da própria vida: biomedicina, poder e subjetividade no século XXI. São Paulo: Paulus.

SCAVONE Lucila. 2004. Dar a vida e cuidar da vida: feminismo e ciências sociais. São Paulo: Unesp.

SCOTT, Russell Parry. 2011a. Famílias Brasileiras: poderes, desigualdades e solidariedades. Recife: EDUFPE. . 2011b. "As famílias que os programas de saúde pública constroem no Brasil". In: Pedro Nascimento, Luís Felipe Rios (orgs.), Gênero, saúde e práticas profissionais. Recife: Ed. Universitária de UFPE.

2020. "Sendo prioridade entre prioridades: Fortalecimento mútuo e desentendimentos na articulação de cuidados entre casa, serviços e áreas de conhecimento In SCOTT, Parry; LIRA, Luciana \& MATOS, Silvana (orgs.). Práticas Sociais no Epicentro da Epidemia do Zika. Recife: EDUFPE. : 23-47.

SCOTT, Russell Parry \& LIRA, Luciana Campelo de. 2020. "A gestão do tempo no tempo da emergência: o cotidiano das mães e crianças afetadas pela Síndrome Congênita do Zika, Ayé. Revista de Antropologia,v. 2, n. 1:14-29.

SCOTT, Russell Parry; LIRA, Luciana Campêlo de; MATOS, Silvana Sobreira de; SOUZA, Fernanda Maria; SILVA, Ana Claudia; QUADROS, Marion Teodósio de. 2018a. "Itinerários terapêuticos, cuidados e atendimento na construção de ideias sobre maternidade e infância no contexto da Zika". Interface (Botucatu), n. 22 (66):673-84. Disponível em: http:// www.scielo.br/pdf/icse/v22n66/18075762-icse-22-66-0673.pdf

SCOTT, Russel Parry; LIRA, Luciana Campelo de \& MEIRA, Fernanda de Souza. 2018b. "Marcações, Mutirões, Altas e Capacitações: Leituras dos encontros comunicativos por cuidadoras no contexto da epidemia da Síndrome Congênita de Zika". "OP 078. Ethnography of the relationship between citizen and state in the context of Zika and other arboviruses". 18th IUAES World Congress". 16 a 20 de julho de 2018, Universidade Federal de Santa Catarina, Florianópolis - SC, Brasil. Disponível em: https://www. pt.iuaes2018.org/conteudo/ view? ID CONTEUDO $=761$

SILVA, Ana Cláudia Rodrigues da; MATOS, Silvana Sobreira de \& QUADROS, Marion Teodósio de. 2017. Economia Política do Zika: Realçando relações entre Estado e cidadão. Revista Anthropológicas, dez. 2017. Disponível em: <https:// periodicos.ufpe.br/revistas/ revistaanthropologicas/article/ view/231440/25547>. Acesso em 24/07/2020. 
SILVA, Rosana Maria Nascimento Castro. 2018. Precariedades oportunas, terapias insulares: Economias políticas da doença e da saúde na experimentação farmacêutica. Tese de Doutorado em Antropologia, UnB, Brasília.

SOUZA LIMA, Antônio Carlos (org.). 2002. Gestar e gerir: estudos para uma antropologia da administração pública. Rio de Janeiro: Relume Dumará.

TRONTO, Joan. 1997. "Mulheres e Cuidados: O que as Feministas Podem Aprender sobre Moralidade". In: JAGGER, Alison M. \& BORDO, Susan R. (eds.), Gênero, Corpo e Conhecimento. Rio de Janeiro: Record/ Rosa dos Tempos.

VIANNA, Adriana \& FARIAS, Juliana. 2011. "A guerra das mães: Dor e política em situações de violência policial". Cadernos Pagu, n. 37:79116. 
CUIDADOS, MOBILIDADE E PODER NUM CONTEXTO DE EPIDEMIA: RELAÇÕES FAMILIARES E ESPAÇOS DE NEGOCIAÇÃO

\section{Resumo}

Cuidar de um filho com Síndrome Congênita de Zika (SCZ) implica numa reelaboração de estratégias de mobilidade de famílias inteiras num novo contexto epidêmico. O trabalho descreve três domínios de cuidados, - relacional, de atendimento, de conhecimento formados em torno da criança afetada por SCZ, por mães, instituições de atendimento e pesquisadores, respectivamente. A pesquisa foi realizada através de observação e participação durante itinerários terapêuticos e entrevistas feitas por uma equipe de antropólogos num projeto do edital nacional (CNPq/CAPES/DECIT) Combate ao Zika entre 2016 e 2020. Aborda etnograficamente a prática e negociação de relações de poder vividas nos diferentes domínios por mães com crianças com SCZ a partir da experiência de três mulheres em Pernambuco. Foca em cuidados e mobilidade em mudanças residenciais, deslocamentos cotidianos e reorganização de redes de relações com pessoas próximas. Mostra que as mães utilizam relações familiares para enfrentar impedimentos nos serviços de atendimento, valorizar as suas próprias ações, e para favorecer sua inserção em associações que favorecem a politização da maternidade na luta para direitos nestes contextos.

Palavras Chaves: Zika, relacões familiares, mobilidade, poder, acesso a direitos.
CARE, MOBILITY AND POWER IN AN EPIDEMIC CONTEXT:

FAM ILY RELATIONS AND SPACES OF NEGOTIATION

\section{Abstract}

Caring for a child with the Zika Congenital Syndrome (SCZ) implies a reelaboration of mobility strategies for entire families in a new epidemic context. The work describes the care domains - relational, service and knowledge - formed around a child with SCZ by mothers, institutions and researchers, respectively, and their relation to power. Observations and participation in therapeutic itineraries and interviews were done by a team of anthropologists in a project on the national call for research on Fighting Zika (CNPq/CAPES/DECIT) between 2016 and 2020. It chooses an ethnographic approach to practice and negotiations experienced in different domains by mothers with children with SCZ based on the experience of three mothers in Pernambuco, Brazil. It focusses on care and mobility in residential changes, daily transportation displacements and the reorganization of networks of closely-related persons. It shows that women use family relations to confront barriers to access to service care, to value their own acts, and to favor their insertion in associations, politicizing maternity and favoring the search for rights in this context.

Key Words: Zika, family relationships, power, mobility, access to rights. 


\section{CUIDADOS, MOVILIDAD Y PODER}

EN UN CONTEXTO DE EPIDEMIA:

RELACIONES FAMILIARES Y

ESPACIOS DE NEGOCIACIÓN

\section{Resumen}

Cuidar de un hijo con el Síndrome Congénito de ZIKA (SCZ) implica una reelaboración de estrategias de movilidad para familias enteras en un contexto nuevo de epidemia. El trabajo describe tres dominios de cuidados - relacional, de atendimientos y de conocimiento - formados en torno de un niño afectado por SCZ, compuesto por madres, instituciones de atendimiento e investigadores, respectivamente. La investigación se realizó a través de observación y participación durante itinerarios terapéuticos y entrevistas hechas por un equipo de antropólogos en un proyecto de llamada nacional (CNPq/ CAPES/DECIT) de Combate al Zika entre 2016 y 2020. Plantea etnográficamente la práctica y negociaciones y relaciones de poder vividas en dominios diferentes por madres con niños con SCZ a partir de la experiencia de tres mujeres en Pernambuco, Brasil. Escoge un enfoque de cuidados y de movilidad en cambios residenciales, desplazamientos cotidianos y reorganización de redes de relaciones con personas cercanas. Muestra que las madres utilizan relaciones familiares para enfrentar impedimentos en los servicios de atendimiento, valorar sus propias acciones y para ampliar su inserción en asociaciones que favorecen la politización de la maternidad en la lucha por derechos en estos contextos.

Palabras Clave: Zika, relaciones familiares, movilidad, poder, acceso a derechos. 